\title{
Article \\ The Biocatalytic Degradation of Organic Dyes Using Laccase Immobilized Magnetic Nanoparticles
}

\author{
Norah Salem Alsaiari ${ }^{1}\left(\mathbb{D}\right.$, Abdelfattah Amari ${ }^{2,3, *(\mathbb{D})}$, Khadijah Mohammedsaleh Katubi ${ }^{1, *(\mathbb{D} \text {, }}$ \\ Fatimah Mohammed Alzahrani ${ }^{1, *} \mathbb{\infty}$, Hamed N. Harharah ${ }^{2} \mathbb{D}$, Faouzi Ben Rebah ${ }^{4} \mathbb{D}$ and Mohamed A. Tahoon ${ }^{5,6}$ \\ 1 Chemistry Department, College of Science, Princess Nourah Bint Abdulrahman University, \\ Riyadh 11671, Saudi Arabia; nsalsaiari@pnu.edu.sa \\ 2 Department of Chemical Engineering, College of Engineering, King Khalid University, \\ Abha 61411, Saudi Arabia; hhharharah@kku.edu.sa \\ 3 Research Laboratory of Energy and Environment, Department of Chemical Engineering, \\ National School of Engineers, Gabes University, Gabes 6072, Tunisia \\ 4 Higher Institute of Biotechnology of Sfax (ISBS), Sfax University, P.O. Box 263, Sfax 3000, Tunisia; \\ benrebahf@yahoo.fr \\ 5 Department of Chemistry, College of Science, King Khalid University, P.O. Box 9004, \\ Abha 61413, Saudi Arabia; tahooon_87@yahoo.com \\ 6 Chemistry Department, Faculty of Science, Mansoura University, Mansoura 35516, Egypt \\ * Correspondence: abdelfattah.amari@enig.rnu.tn (A.A.); kmkatubi@pnu.edu.sa (K.M.K.); \\ fmalzahrani@pnu.edu.sa (F.M.A.)
}

check for updates

Citation: Alsaiari, N.S.; Amari, A.; Katubi, K.M.; Alzahrani, F.M.; Harharah, H.N.; Rebah, F.B.;

Tahoon, M.A. The Biocatalytic Degradation of Organic Dyes Using Laccase Immobilized Magnetic Nanoparticles. Appl. Sci. 2021, 11 , 8216. https://doi.org/10.3390/ app11178216

Academic Editor: Costica Caizer

Received: 12 August 2021

Accepted: 1 September 2021

Published: 4 September 2021

Publisher's Note: MDPI stays neutral with regard to jurisdictional claims in published maps and institutional affiliations.

Copyright: (c) 2021 by the authors. Licensee MDPI, Basel, Switzerland. This article is an open access article distributed under the terms and conditions of the Creative Commons Attribution (CC BY) license (https:// creativecommons.org/licenses/by/ $4.0 /)$.

\begin{abstract}
Free laccase has limitations for its use in industrial applications that require laccase immobilization on proper support, to improve its catalytic activity. Herein, the nanoparticles of magnetic iron oxide $\left(\mathrm{Fe}_{3} \mathrm{O}_{4}\right)$ and copper ferrite $\left(\mathrm{CuFe}_{2} \mathrm{O}_{4}\right)$ were successfully used as support for the immobilization of free laccase, using glutaraldehyde as a cross-linker. The immobilization conditions of laccase on the surface of nanoparticles were optimized to reach the maximum activity of the immobilized enzyme. The synthesized free nanoparticles and the nanoparticle-immobilized laccase were characterized using different techniques, including X-ray diffraction (XRD), Fourier transform infrared spectroscopy (FT-IR), scanning electron microscope (SEM), vibrating sample magnetometer (VSM), and thermogravimetric analysis (TGA). $\mathrm{CuFe}_{2} \mathrm{O}_{4}$ nanoparticles, as support, enhanced laccase activity compared to free laccase and $\mathrm{Fe}_{3} \mathrm{O}_{4}$ nanoparticle-immobilized laccase that appeared during the study of $\mathrm{pH}$, temperature, and storage stability on free and immobilized laccase. The $\mathrm{CuFe}_{2} \mathrm{O}_{4}$ and $\mathrm{Fe}_{3} \mathrm{O}_{4}$ nanoparticle-immobilized laccase showed superior activity in a wide $\mathrm{pH}$ range, temperature range, and storage period, up to 20 days at $4.0^{\circ} \mathrm{C}$, when compared to free laccase. Additionally, the synthesized nanobiocatalysts were examined and optimized for the biodegradation of the anionic dye Direct Red 23 (DR23). HPLC analysis was used to confirm the dye degradation. The reusability of immobilized laccases for the biodegradation of DR23 dye was investigated for up to six successive cycles, with a decolorization efficiency over $70.0 \%$, which indicated good reusability and excellent stability.
\end{abstract}

Keywords: activity enhancement; immobilization; magnetic nanoparticles; laccase; biodegradation

\section{Introduction}

The economy and development of the present world are essentially dependent on the industries. However, the other face of industrial development is the pollution of the environment, due to the release of toxic materials associated with different industries [1] The presence of these materials is a great risk to the living ecosystem, because of their confirmed mutagenic and carcinogenic properties [2,3]. So, these harmful materials must be removed safely from different environmental systems. Dyes that are released into the environment through different printing and textile activities are an example of these dangerous pollutants $[4,5]$. These dyes were removed from contaminated industrial wastewater via 
several biological and chemical methods. Attention is drawn to using biological methods, including enzymes, instead of chemical methods, due to limitations such as the discharge of harmful by-products, high cost, and ineffective purification [6]. These dyes' biodegradation is extensively investigated, using several peroxidases and oxidases [7-9]. The laccase enzyme is a multi-copper oxidase that is formed by several plants and fungi, and can oxidize different types of dyes in an eco-friendly and effective way [10]. However, the laccase's weak stability and difficult reusability limit its application in the water treatment from such contaminants [11]. Besides the non-reusability and low stability of soluble laccase, it is very sensitive towards denaturing agents that retard its function and hinder its use in real sample applications. These problems can be resolved by the laccase hold method on different types of supports, to enhance enzyme stability. Different carriers are used to support the laccase enzyme, and improve its catalytic efficiency and stability, and this process is known as immobilization. The immobilization of different biomolecules and enzymes is achieved by using many approaches, such as encapsulations, entrapment, crosslinking, adsorption, and covalent bonding [12]. The enzyme immobilization was reached using different types of materials, including inorganic materials (silica, metal oxides, and clays) [13-15], organic materials (natural and synthetic polymers) [16,17], and hybrids (joining organic and inorganic materials) [18]. Among all the materials used, nanomaterials are widely used due to their exceptional properties [19-24], such as high surface area, ease of synthesis, low cost, and ease of modification that can enhance the enzymatic activity. Many studies reported the successful immobilization of laccase on the surface of nanomaterials, to improve its stability and catalytic properties, for the removal of the dye from aqueous media. For instance, free laccase was successfully immobilized with improved properties and reused on the surface of green synthesized $\mathrm{ZnO}$ and $\mathrm{MnO}$ nanoparticles for the degradation of alizarin red $S$ dye [25]. From nanomaterials, magnetic nanoparticles are the most used and favored as support for enzymes, due to their magnetic behavior that allows the magnetic separation from the reaction medium, using an external magnet. For example, a magnetic amino-functionalized metal-organic framework $\left(\mathrm{Fe}_{3} \mathrm{O}_{4}-\mathrm{NH}_{2} @ \mathrm{MIL}-101(\mathrm{Cr})\right)$ was successfully used for the immobilization of laccase, for the biodegradation of Reactive Black 5 (RB) and alizarin red S (AR) dyes in water [26], while a magnetic nanocomposite $\left(\mathrm{Fe}_{3} \mathrm{O}_{4} /\right.$ chitosan) was used for the successful immobilization of manganese peroxidase, for the removal of orange 16 and methylene blue [27]. The implantation of some heavy metals with the magnetic nanoparticles significantly enhances their immobilization efficiency for laccase, besides applied operability. Additionally, several heavy metals, such as cobalt, calcium, zinc, and copper, were reported in many works to improve the laccase activity [28]. Especially, copper ions at low concentrations serve as laccase modulators more than other heavy metals [29]. Accordingly, the laccase enzyme in the present study was immobilized on the surface of synthesized iron oxide nanoparticles $\left(\mathrm{Fe}_{3} \mathrm{O}_{4}\right)$ and copper ferrite magnetic nanoparticles $\left(\mathrm{CuFe}_{2} \mathrm{O}_{4}\right)$. The added copper helped the improvement of the laccase activity. The synthesized nanomaterials were characterized in detail. The effect of different parameters on dye degradation, using synthesized nanobiocatalysts, was studied. Additionally, the kinetics and reusability of the nanobiocatalysts for the removal of the dye were determined.

\section{Materials and Methods}

\subsection{Chemicals}

Ferric chloride hexahydrate $\left(\mathrm{FeCl}_{3} \cdot 6 \mathrm{H}_{2} \mathrm{O}\right)$, ferrous chloride tetrahydrate $\left(\mathrm{FeCl}_{2} \cdot 4 \mathrm{H}_{2} \mathrm{O}\right)$, cupric chloride dihydrate $\left(\mathrm{CuCl}_{2} \cdot 2 \mathrm{H}_{2} \mathrm{O}\right)$, Direct Red 23 (DR23), 3-aminopropyl triethoxysilane (APTES), laccase (from Trametes versicolor) glutaraldehyde, and 2,2'-azino-bis (3ethylbenzothiazoline-6-sulfonate) (ABTS) were purchased from Sigma-Aldrich. All used chemicals are of analytical grade and used as received without any modification. 


\subsection{Synthesis of $\mathrm{Fe}_{3} \mathrm{O}_{4}$ Magnetic Nanoparticles}

The reported co-precipitation method [30] was used for the synthesis of magnetic nanoparticles as briefly discussed in this section. Firstly, we dissolved ferric chloride hexahydrate $\left(\mathrm{FeCl}_{3} \cdot 6 \mathrm{H}_{2} \mathrm{O}\right)$ and ferrous chloride tetrahydrate $\left(\mathrm{FeCl}_{2} \cdot 4 \mathrm{H}_{2} \mathrm{O}\right)$ with a molar ratio of 2:1, respectively, in $45.0 \mathrm{~mL}$ of deionized $\mathrm{H}_{2} \mathrm{O}$ with sonication. The mixture was shaken at $70.0^{\circ} \mathrm{C}$ and $1000 \mathrm{rpm}$ for about $35.0 \mathrm{~min}$. After that, the aqueous solution of sodium hydroxide $(\mathrm{NaOH}, 25 \%)$ was added stepwise to the previous mixture until a black precipitate was formed. The black precipitate was washed three times with deionized $\mathrm{H}_{2} \mathrm{O}$ after being separated from the solution using an external magnet. Finally, the synthesized magnetic nanoparticles were dried at room temperature for $24 \mathrm{~h}$ to be ready for use.

\subsection{Synthesis of Copper Ferrite $\left(\mathrm{CuFe}_{2} \mathrm{O}_{4}\right)$ Magnetic Nanoparticles}

The co-precipitation reported method [31] was used for the synthesis of $\mathrm{CuFe}_{2} \mathrm{O}_{4}$ nanoparticles as follows. Under an argon atmosphere, we dissolved cupric chloride dihydrate $\left(\mathrm{CuCl}_{2} \cdot 2 \mathrm{H}_{2} \mathrm{O}\right)$ and ferric chloride hexahydrate $\left(\mathrm{FeCl}_{3} \cdot 6 \mathrm{H}_{2} \mathrm{O}\right)$ in $76.0 \mathrm{~mL}$ deionized $\mathrm{H}_{2} \mathrm{O}$ with a molar ratio of 1:2, respectively, with vigorous stirring for $10.0 \mathrm{~min}$. After that, an aqueous solution of sodium hydroxide $(0.005 \mathrm{M})$ was added slowly to the previous mixture with continuous stirring until a black precipitate was formed. The solution was then stirred for $5 \mathrm{~h}$ at $90.0^{\circ} \mathrm{C}$. The black precipitate of $\mathrm{CuFe}_{2} \mathrm{O}_{4}$ nanoparticles was washed several times with deionized $\mathrm{H}_{2} \mathrm{O}$ and ethyl alcohol after being separated from the reaction solution using an external magnet. Finally, the precipitate was dried for $24.0 \mathrm{~h}$ at $85.0^{\circ} \mathrm{C}$ in the oven and calcinated for $5 \mathrm{~h}$ at $700.0^{\circ} \mathrm{C}$.

\subsection{Immobilization of Laccase on Synthesized Nanoparticles}

For the immobilization of laccase enzyme on the surface of synthesized $\mathrm{Fe}_{3} \mathrm{O}_{4}$ and $\mathrm{CuFe}_{2} \mathrm{O}_{4}$ nanoparticles, their surfaces were firstly amino-functionalized. This can be reached using 3-aminopropyl triethoxysilane (APTES) as a modifying agent. Then, $200.0 \mathrm{~mL}$ of 1:1 mixed solvent (ethanol $/ \mathrm{H}_{2} \mathrm{O}$ ) was used to disperse $1.0 \mathrm{~g}$ of the nanoparticles under ultra-sonication for $35.0 \mathrm{~min}$. Then, the previously suspended mixtures were stirred vigorously with the gradual addition of $10.0 \%$ solution of APTES and the stirring was continued at $70.0^{\circ} \mathrm{C}$ for five hours. The mixed solvent of ethanol $/ \mathrm{H}_{2} \mathrm{O}$ was used for washing the amino-functionalized nanoparticles several times to remove any free APTES from their surfaces followed by drying the nanoparticles for 24.0 at room temperature. Then, a solution of sodium citrate buffer $(\mathrm{pH}=4.8,100.0 \mathrm{mM})$ was used to disperse the functionalized nanoparticles $\left(\mathrm{Fe}_{3} \mathrm{O}_{4}\right.$ or $\left.\mathrm{CuFe}_{2} \mathrm{O}_{4}\right)$ and laccase enzyme with a nanoparticles:laccase ratio of 1.0:0.5, and 1:7.0 in the case of $\mathrm{Fe}_{3} \mathrm{O}_{4}$ and $\mathrm{CuFe}_{2} \mathrm{O}_{4}$, respectively. The enzyme nanoparticles mixtures were incubated at $30.0^{\circ} \mathrm{C}$ and stirred for half an hour at $150.0 \mathrm{rpm}$. After that, glutaraldehyde as a cross-linker with a concentration of $50 \mathrm{mM}$ was added and incubated for $9 \mathrm{~h}$ with stirring at $150.0 \mathrm{rpm}$. The immobilization conditions included (nanoparticles:enzyme ratio, glutaraldehyde concentration, and cross-linking incubation time) were determined in preliminary studies to determine the optimum conditions for the immobilization. Then, the immobilized $\mathrm{Fe}_{3} \mathrm{O}_{4}$ and $\mathrm{CuFe}_{2} \mathrm{O}_{4}$ were washed several times with the citrate buffer after being separated with an external magnet. For the storing of the immobilized $\mathrm{Fe}_{3} \mathrm{O}_{4}$ and $\mathrm{CuFe}_{2} \mathrm{O}_{4}$, the citrate buffer was used at a temperature of $4.0^{\circ} \mathrm{C}$.

\subsection{Assay for Laccase Activity}

ABTS as substrate was used for the determination of the activities of free laccase and nanoparticle-immobilized laccase $\left(\mathrm{Fe}_{3} \mathrm{O}_{4}\right.$ and $\left.\mathrm{CuFe}_{2} \mathrm{O}_{4}\right)$. Sodium citrate buffer $(350.0 \mu \mathrm{L}$, $\mathrm{pH}=4.8,100.0 \mathrm{mM})$ was mixed with $100.0 \mu \mathrm{L}$ of enzyme and ABTS $(50.0 \mu \mathrm{L}, 10.0 \mathrm{mM})$. Then, the mixture was quietly shacked for $10.0 \mathrm{~min}$ at a temperature of $25.0^{\circ} \mathrm{C}$. The quantity of enzyme necessary to catalyze the oxidation of $1.0 \mu \mathrm{mol}$ of ABTS per minute was one unit of laccase activity. UV-vis spectrophotometer $(\lambda=420.0 \mathrm{~nm})$ was used to determine the oxidized substrate (blue-green color) as the enzyme oxidizes the ABTS to its oxidized form $\mathrm{ABTS}^{+}$. 


\subsection{The Stability of Free and Immobilized Laccase}

2.6.1. Temperature and $\mathrm{pH}$ Effect

The free laccase, $\mathrm{Fe}_{3} \mathrm{O}_{4}$ nanoparticle-immobilized laccase, and $\mathrm{CuFe}_{2} \mathrm{O}_{4}$ nanoparticleimmobilized laccase were incubated for $60.0 \mathrm{~min}$ in a buffer of sodium citrate $(\mathrm{pH}=4.8$, $100.0 \mathrm{mM}$ ) in the temperature range of $30.0{ }^{\circ} \mathrm{C}$ to $70.0{ }^{\circ} \mathrm{C}$ to study the temperature effect. Also, the incubation of immobilized and free laccase was performed for $60.0 \mathrm{~min}$ at a temperature of $50.0^{\circ} \mathrm{C}$ in different buffer solutions ranging from 3.0 to 9.0 to study the $\mathrm{pH}$ effect. The relative laccase activity after that was determined for different samples, assuming $100 \%$ for the highest activity.

\subsubsection{Storage Stability}

The free laccase, $\mathrm{Fe}_{3} \mathrm{O}_{4}$ nanoparticle-immobilized laccase, and $\mathrm{CuFe}_{2} \mathrm{O}_{4}$ nanoparticleimmobilized laccase were studied for storage stability by using a buffer of sodium citrate $(\mathrm{pH}=4.8,100.0 \mathrm{mM})$ to store the samples at a temperature of $4.0^{\circ} \mathrm{C}$ for 20 days. During the 20 day storage period, the laccase activities were determined every 4 days. The laccase $100 \%$ activity was considered to be the initial activity.

\subsubsection{Kinetic Parameters}

A sodium citrate buffer $(\mathrm{pH}=4.8,100.0 \mathrm{mM})$ with different ABTS concentrations ranging from $0.20 \mathrm{mg} / \mathrm{mL}$ to $0.60 \mathrm{mg} / \mathrm{mL}$ was used for the calculation of free and immobilized laccase kinetic parameters, including maximum reaction rate $\left(\mathrm{V}_{\max }\right)$ and Michaelis-Menten kinetic constant $\left(\mathrm{K}_{\mathrm{m}}\right)$. Lineweaver-Burk plot was used for the calculation of kinetic parameters $\mathrm{V}_{\max }$ and $\mathrm{K}_{\mathrm{m}}$ from intercept and slope, respectively.

\subsection{Biodegradation of DR23 Dye}

The immobilized laccase was studied for the degradation of DR23 with the study of the effect of nano-biosorbents dosage in the range of $60 \mathrm{mg} / \mathrm{mL}$ to $300 \mathrm{mg} / \mathrm{mL}$ and the effect of dye concentration in the range of $10 \mathrm{mg} / \mathrm{mL}$ to $50 \mathrm{mg} / \mathrm{mL}$. The biodegradation process was performed at a temperature of $50.0^{\circ} \mathrm{C}$ and $\mathrm{pH}$ of 5.0 with repetition of the experiment three times to determine the errors. A UV/visible spectrophotometer was used for the determination of DR23 concentrations at $\lambda_{\max }=507 \mathrm{~nm}$. The decolorization of the dye was calculated using the following equation:

$$
\text { Decolorization }(\%)=\left(\mathrm{Abs}_{\mathrm{i}}-\mathrm{Abs}_{\mathrm{f}} / \mathrm{Abs}_{\mathrm{i}}\right) \times 100 \text {, }
$$

where the symbols $\mathrm{Abs}_{\mathrm{i}}$ and $\mathrm{Abs}_{\mathrm{f}}$ denote the initial absorbance and final absorbance, respectively.

The reusability of the immobilized laccase on both supports $\left(\mathrm{Fe}_{3} \mathrm{O}_{4}\right.$ and $\mathrm{CuFe}_{2} \mathrm{O}_{4}$ nanoparticles) for the degradation of DR23 was studied for up to five successive cycles. The first cycle obtained efficiency for the dye degradation that was considered to be $100.0 \%$ efficiency. The degradation conditions were adjusted as optimum conditions of $\mathrm{pH}$, temperature, dosage, and dye concentration. After each cycle, the nano-biosorbent was washed several times with buffer solution after being collected from the reaction medium using an external magnet. Then, the nano-biosorbent was used to study the next cycle.

\section{Results and Discussion}

\subsection{The Characterization of Synthesized Materials}

The immobilization conditions included (nanoparticles:enzyme ratio, glutaraldehyde concentration, and cross-linking incubation time) were optimized to get the maximum activity of the laccase enzyme. The nanoparticles:laccase ratios $(w / w)$ were 1.0:0.5 and 1:7.0 in the case of $\mathrm{Fe}_{3} \mathrm{O}_{4}$ and $\mathrm{CuFe}_{2} \mathrm{O}_{4}$, respectively, while the concentration of glutaraldehyde as a cross-linker was $50 \mathrm{mM}$, and the incubation time was $9 \mathrm{~h}$. These optimized conditions provided the maximum activities of laccase that were $90.0 \%$ and $95.0 \%$ in the case of $\mathrm{Fe}_{3} \mathrm{O}_{4}$ and $\mathrm{CuFe}_{2} \mathrm{O}_{4}$, respectively. 
To confirm the structure, morphology, and size of the synthesized nanomaterials, $\mathrm{Fe}_{3} \mathrm{O}_{4}, \mathrm{CuFe}_{2} \mathrm{O}_{4}$, and their nanoparticles immobilized enzyme, different characterization techniques were used, as discussed in the next section. Firstly, X-ray diffraction (XRD) was used for the characterization of synthesized free and immobilized nanoparticles, as shown in Figure 1a. According to Figure 1a, the 2-theta values with high intensities correspond to the planes (440), (511), (400), (311), and (220) for free and immobilized $\mathrm{Fe}_{3} \mathrm{O}_{4}$ and $\mathrm{CuFe}_{2} \mathrm{O}_{4}$ nanoparticles that appeared at $62.39,57.99,43.82,35.25$, and $33.64^{\circ}$, respectively. The XRD results indicated that $\mathrm{Fe}_{3} \mathrm{O}_{4}$ and $\mathrm{CuFe}_{2} \mathrm{O}_{4}$ nanoparticles have spinel crystal structures with face-centered cubic structure, as reported in the literature [32]. The laccase immobilization on the surface of the nanoparticles did not changed the phase and the nature of the synthesized nanoparticles, as indicated by the XRD results. The average size of $\mathrm{Fe}_{3} \mathrm{O}_{4}$ and $\mathrm{CuFe}_{2} \mathrm{O}_{4}$ nanoparticles, calculated using the Scherrer equation, was equal to 18.30 and $21.30 \mathrm{~nm}$, respectively. Moreover, the sharp and strong XRD peaks of the nanoparticles indicated the crystallinity nature of the synthesized nanoparticles. For the study of the present functional groups in the synthesized nanoparticles, the FT-IR spectra of free $\mathrm{Fe}_{3} \mathrm{O}_{4}$ and $\mathrm{CuFe}_{2} \mathrm{O}_{4}$ nanoparticles, and their nanoparticle-immobilized laccase, are shown in Figure $1 \mathrm{~b}$. According to Figure $1 \mathrm{~b}$, the $\mathrm{Cu}-\mathrm{O}$ octahedral metal oxides and $\mathrm{Fe}-\mathrm{O}$ tetrahedral stretching vibration bands of the synthesized $\mathrm{CuFe}_{2} \mathrm{O}_{4}$ and $\mathrm{Fe}_{3} \mathrm{O}_{4}$ nanoparticles were observed at 550.0 and $400.0 \mathrm{~cm}^{-1}$, respectively. Free -OH stretching vibrations and $\mathrm{CH}_{2}$ rocking vibrations appeared at 3421 and $813 \mathrm{~cm}^{-1}$, respectively [33], in the spectra of $\mathrm{CuFe}_{2} \mathrm{O}_{4}$ nanoparticles, $\mathrm{Fe}_{3} \mathrm{O}_{4}$ nanoparticles, and their nanoparticle-immobilized laccase. The spinel ferrite was confirmed due to the clear bands that appeared in the region of 400.0 to $600.0 \mathrm{~cm}^{-1}$ [32], which confirms the XRD results. Stretching vibrations of $\mathrm{N}-\mathrm{H}$ and $\mathrm{Si}-\mathrm{O}-\mathrm{Fe}$ that appeared as new bands in the spectra of nanoparticle-immobilized laccase were observed at 3481 and $1201 \mathrm{~cm}^{-1}$, respectively [33], and appeared due to the immobilization that followed the silanization. The attached $\mathrm{H}_{2} \mathrm{O}$ molecules on the surface of the nanoparticle-immobilized laccase were represented by the band at $1651 \mathrm{~cm}^{-1}$ [34], which represents the bending $\mathrm{H}-\mathrm{O}-\mathrm{H}$ vibration. Additionally, the vibrating sample magnetometer (VSM) was used to investigate the magnetic properties of the synthesized nanoparticles $\mathrm{Fe}_{3} \mathrm{O}_{4}$ and $\mathrm{CuFe}_{2} \mathrm{O}_{4}$, and their nanoparticle-immobilized laccase, as shown in Figure 1c. According to Figure 1c, the $\mathrm{Fe}_{3} \mathrm{O}_{4}$ nanoparticle-immobilized laccase and $\mathrm{CuFe}_{2} \mathrm{O}_{4}$ nanoparticle-immobilized laccase showed a reduction in the saturation magnetization $\left(\mathrm{M}_{\mathrm{S}}\right)$ that equaled to 23.0 and $9.90 \mathrm{emu}^{-1}$, respectively, when compared to the free $\mathrm{Fe}_{3} \mathrm{O}_{4}$ nanoparticles and $\mathrm{CuFe}_{2} \mathrm{O}_{4}$ nanoparticles, with $\mathrm{M}_{\mathrm{s}}$ values of 25.40 and $12.27 \mathrm{emu} \mathrm{g}^{-1}$, respectively. The successful immobilization of nanoparticles was approved from the reduction in $\mathrm{M}_{\mathrm{s}}$ values, as the immobilized enzyme obstacles the magnetic domain of nanoparticles. There is an agreement between the magnetization results and the values in previous studies [35,36].

Also, the thermogram outline of the synthesized nanoparticles and their nanoparticleimmobilized laccase was investigated using thermogravimetric analysis (TGA), as shown in Figure 1d. In the studied temperature range (100.0 to $450.0^{\circ} \mathrm{C}$ ), the $\mathrm{Fe}_{3} \mathrm{O}_{4}$ and $\mathrm{CuFe}_{2} \mathrm{O}_{4}$ nanoparticles showed weight loss of 3.0 and $10.5 \%$, respectively, while these values increased after the immobilization of laccase to 8.9 and $15.5 \%$, which indicated the successful immobilization. At the temperature of $150.0^{\circ} \mathrm{C}$, an identical weight loss \% was observed for the free laccase and nanoparticle-immobilized laccase, due to the evaporation of adsorbed water molecules and light molecules. When the temperature increased from $150.0^{\circ} \mathrm{C}$ to $300.0^{\circ} \mathrm{C}$, the immobilized nanoparticles showed a greater weight loss $\%$, due to the decomposition of enzymatic proteins. While at a temperature higher than $300.0^{\circ} \mathrm{C}$, the organic molecules were completely decomposed, causing the highest increase in the weight loss \%. For the study of synthesized $\mathrm{Fe}_{3} \mathrm{O}_{4}$ and $\mathrm{CuFe}_{2} \mathrm{O}_{4}$ nanoparticles' morphologies and sizes, SEM analysis was performed, as shown in Figure 2. Figure 2a shows the SEM image of $\mathrm{Fe}_{3} \mathrm{O}_{4}$ nanoparticles with an average particle size of $60.0 \mathrm{~nm}$, while Figure $2 \mathrm{~b}$ shows the SEM image of $\mathrm{CuFe}_{2} \mathrm{O}_{4}$ nanoparticles with an average particle size of $50.0 \mathrm{~nm}$. According to the SEM images of $\mathrm{Fe}_{3} \mathrm{O}_{4}$ and $\mathrm{CuFe}_{2} \mathrm{O}_{4}$ nanoparticles, the particles are sponge-like, 
with a spherical shape and some agglomerations. Additionally, little plate-like particles appeared in the SEM images of the nanoparticles. Figure 2c shows the SEM image of the $\mathrm{Fe}_{3} \mathrm{O}_{4}$ nanoparticle-immobilized laccase, while Figure 2d shows the SEM image of the $\mathrm{CuFe}_{2} \mathrm{O}_{4}$ nanoparticle-immobilized laccase. The SEM images of the nanoparticleimmobilized laccases show a large difference in morphology between the free laccase and nanoparticle-immobilized laccase, which indicated the successful immobilization process.

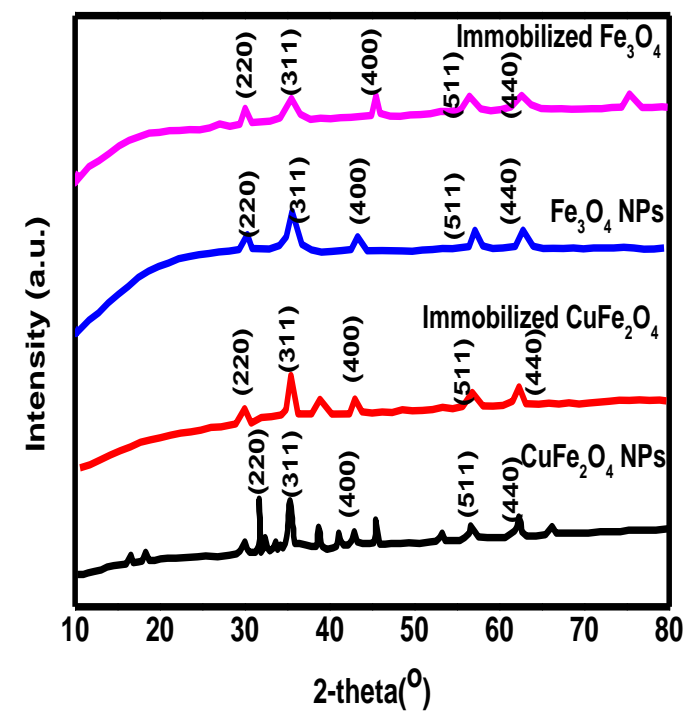

(a)

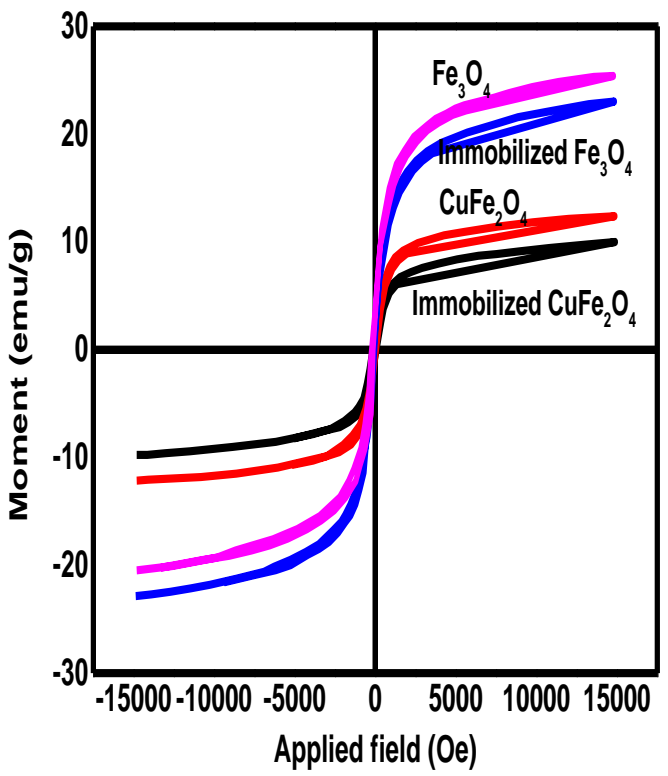

(c)

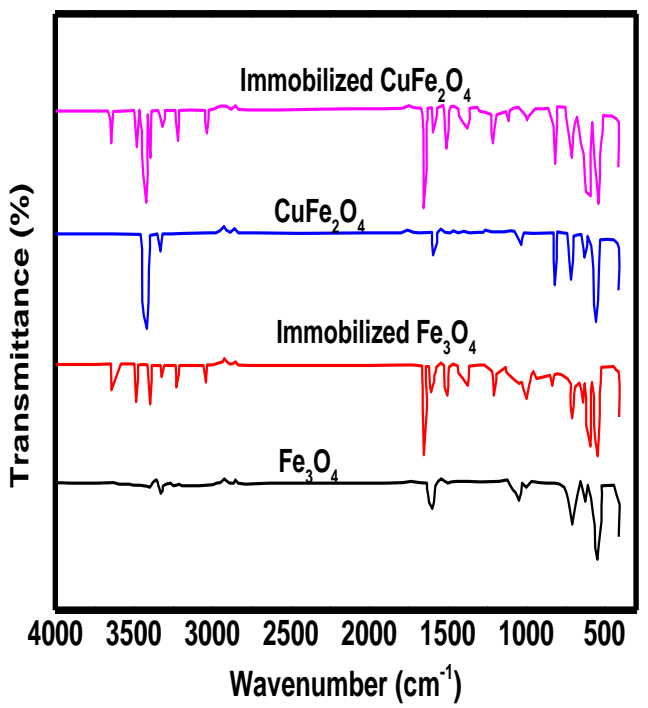

(b)

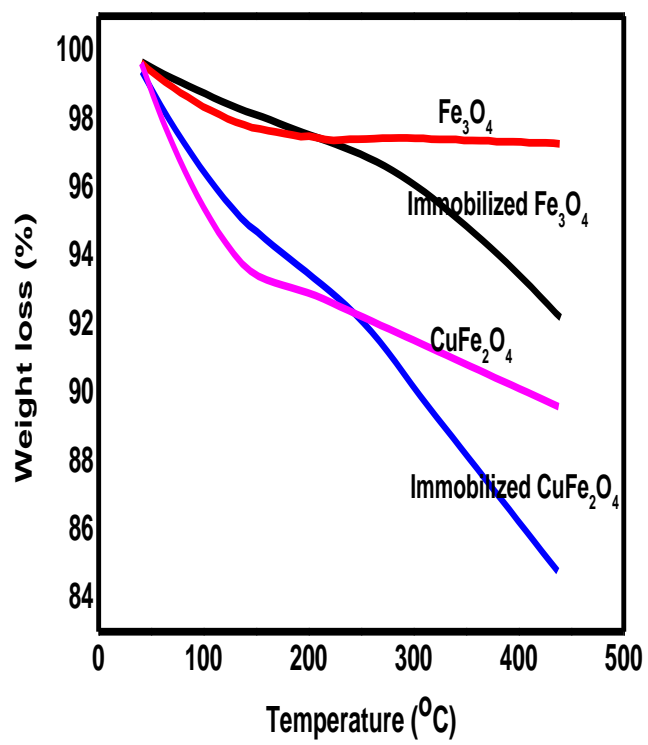

(d)

Figure 1. XRD (a), FT-IR (b), TGA curves (c), and magnetization curves (d) of synthesized $\mathrm{Fe}_{3} \mathrm{O}_{4}$ nanoparticles, $\mathrm{CuFe}_{2} \mathrm{O}_{4}$ nanoparticles, and nanoparticle-immobilized laccase. 


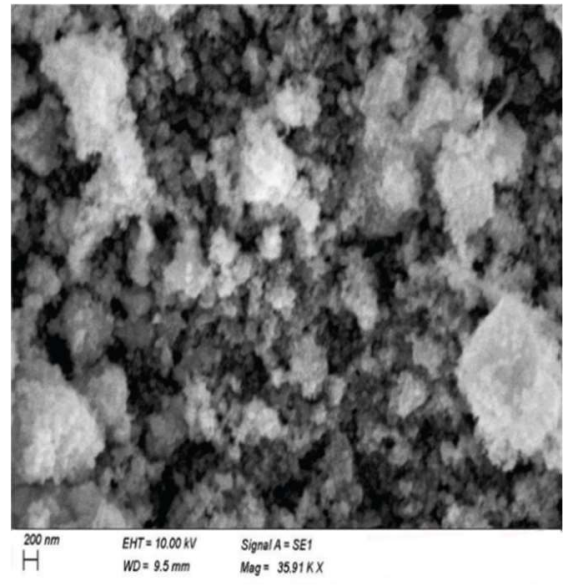

(a)

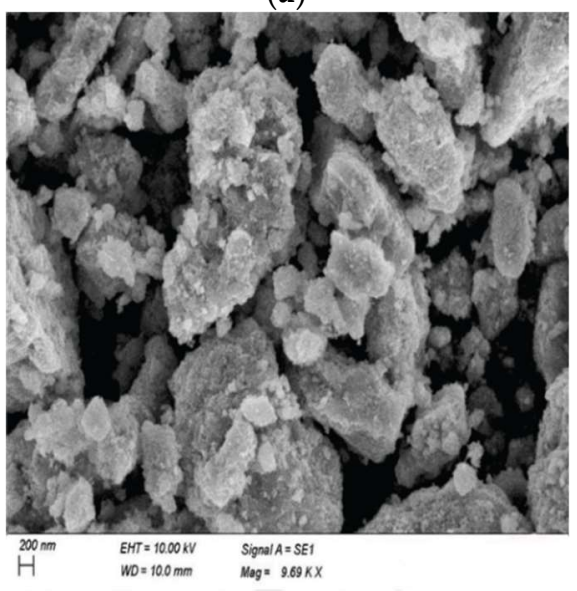

(c)

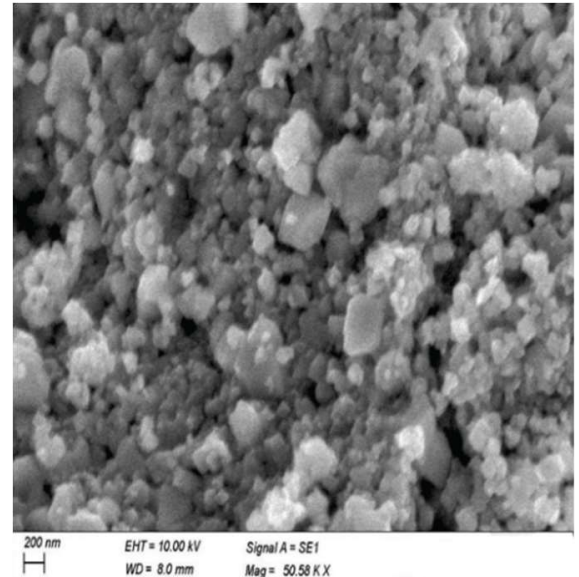

(b)

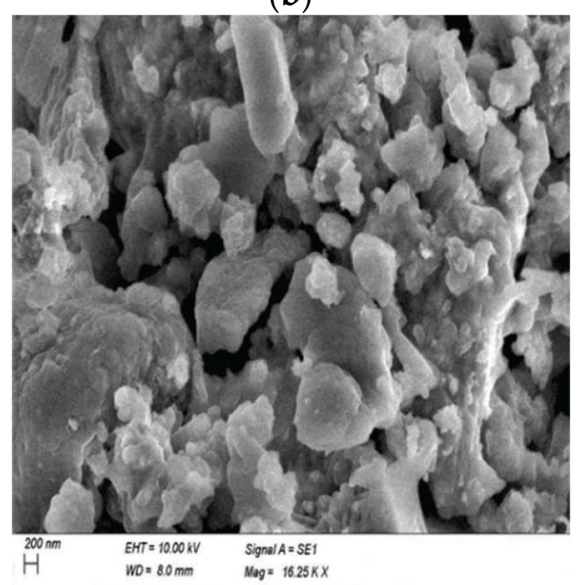

(d)

Figure 2. $\mathrm{SEM}$ images of $\mathrm{Fe}_{3} \mathrm{O}_{4}$ nanoparticles (a), $\mathrm{CuFe}_{2} \mathrm{O}_{4}$ nanoparticles (b), $\mathrm{Fe}_{3} \mathrm{O}_{4}$ nanoparticleimmobilized laccase (c), and $\mathrm{CuFe}_{2} \mathrm{O}_{4}$ nanoparticle-immobilized laccase (d).

\subsection{The Stability of Free and Immobilized Laccase}

The application of immobilized enzymes in real sample treatment requires the assessment of the immobilized laccase's stability under severe conditions. So, the next sections discuss the efficiency of $\mathrm{Fe}_{3} \mathrm{O}_{4}$ and $\mathrm{CuFe}_{2} \mathrm{O}_{4}$ nanoparticles as support for the laccase enzyme, under the conditions of temperature, $\mathrm{pH}$ change, and storage stability.

\subsubsection{Storage Stability of Free and Immobilized Laccase}

$\mathrm{Fe}_{3} \mathrm{O}_{4}$ and $\mathrm{CuFe}_{2} \mathrm{O}_{4}$ nanoparticle-immobilized laccase, as well as free laccase, were kept for 20 days at a temperature of $4.0^{\circ} \mathrm{C}$, in a buffer solution of sodium citrate, to study their storage stability, as shown in Figure 3a. According to Figure 3a, the free laccase lost $71.0 \%$ of its initial activity after the storage for 20 days, while the $\mathrm{Fe}_{3} \mathrm{O}_{4}$ and $\mathrm{CuFe}_{2} \mathrm{O}_{4}$ nanoparticle-immobilized laccases lost only $27.0 \%$ of their initial activity within the same period. The nanoparticles of $\mathrm{Fe}_{3} \mathrm{O}_{4}$ and $\mathrm{CuFe}_{2} \mathrm{O}_{4}$, as support for laccase, made the enzyme retain its activity and resist the changes in its structure. The enzymatic active sites' distortion that causes the conformational modification was prevented in the immobilized laccase, due to the contact between laccase and $\mathrm{Fe}_{3} \mathrm{O}_{4}$ or $\mathrm{CuFe}_{2} \mathrm{O}_{4}$ nanoparticles, by covalent linkages. Also, the $\mathrm{CuFe}_{2} \mathrm{O}_{4}$ nanoparticle-immobilized laccase reserves its activity more than the $\mathrm{Fe}_{3} \mathrm{O}_{4}$ nanoparticle-immobilized laccase, which indicated the great effect of copper ions on the laccase activity. This laccase stimulation occurs by the binding of copper ions to laccase enzymes via the Cu-binding sites of type-2. 


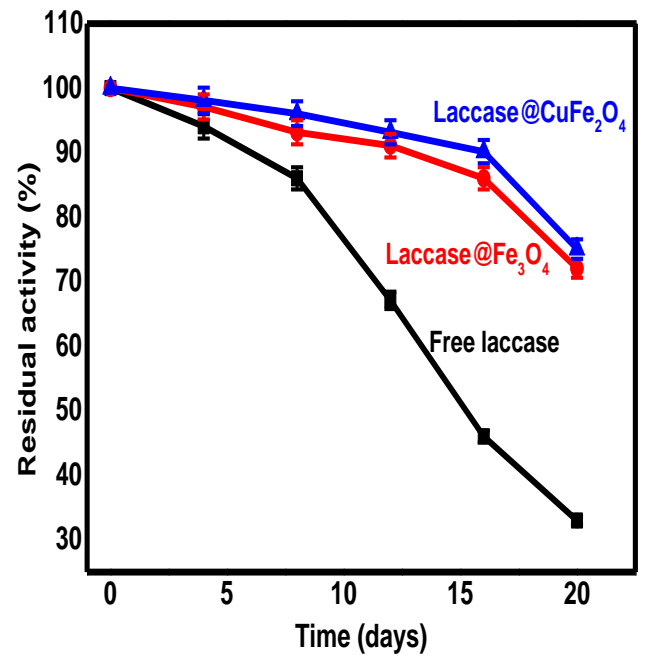

(a)

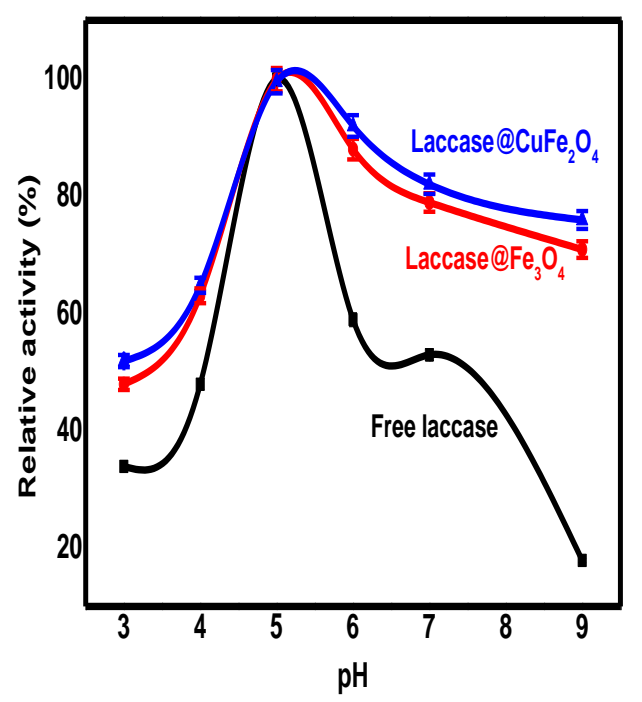

(b)

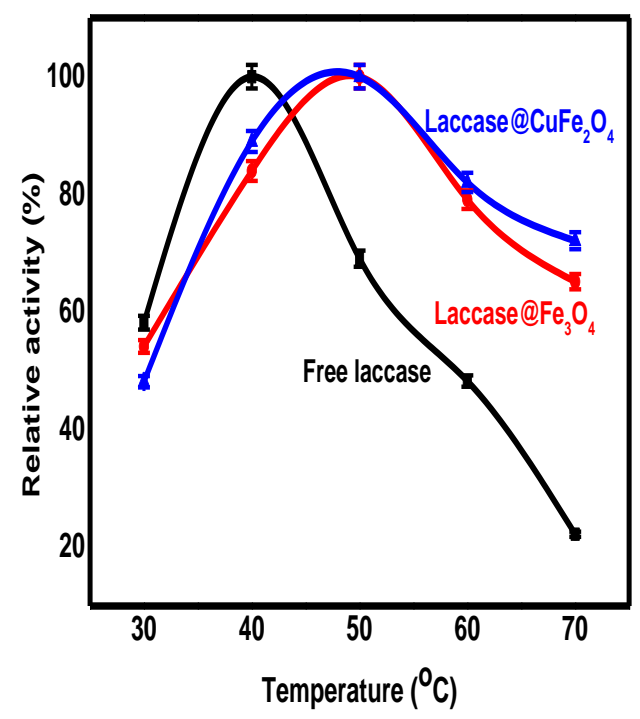

(c)

Figure 3. Storage stability (a), $\mathrm{pH}$ effect (b), and temperature effect (c) on free and immobilized laccase.

\subsubsection{The $\mathrm{pH}$ Effect}

The effect of $\mathrm{pH}$ on free laccase and nanoparticle-immobilized laccase was investigated in the range of 3.0 to 9.0, and the results are presented in Figure 3b. According to Figure 3b, free laccase and immobilized laccases show their maximum enzymatic activity at a $\mathrm{pH}$ of 5.0. So, the optimum $\mathrm{pH}$ of free and immobilized laccases is 5.0. Regardless of the $\mathrm{pH}$ of 5.0, the free laccase exhibited lower enzymatic activity than the immobilized laccases, which indicated the resistance of immobilized laccases on $\mathrm{Fe}_{3} \mathrm{O}_{4}$ and $\mathrm{CuFe}_{2} \mathrm{O}_{4}$ nanoparticles to the $\mathrm{pH}$ change compared to the free laccase. This wide $\mathrm{pH}$ range of immobilized laccase high activity could result from intermolecular interactions between the glutaraldehyde surrounding the active sites and the amino acid side chains of laccase. This interaction also prevents the laccase from unfolding, and subsequently resists the change in $\mathrm{pH}$. Moreover, the $\mathrm{CuFe}_{2} \mathrm{O}_{4}$ nanoparticle-immobilized laccase showed more resistance to $\mathrm{pH}$ change 
than the $\mathrm{Fe}_{3} \mathrm{O}_{4}$ nanoparticle-immobilized laccase, due to the presence of copper ions, as discussed in the previous subsection.

\subsubsection{The Temperature Effect}

The temperature influence on free laccase and nanoparticle-immobilized laccase was investigated by the incubation for $60.0 \mathrm{~min}$ in a buffer solution of sodium citrate $(\mathrm{pH}=4.8$, $100.0 \mathrm{mM}$ ), in the range of 30.0 to $70.0^{\circ} \mathrm{C}$, and the results are presented in Figure 3c. According to Figure $3 \mathrm{c}, \mathrm{Fe}_{3} \mathrm{O}_{4}$ and $\mathrm{CuFe}_{2} \mathrm{O}_{4}$ nanoparticle-immobilized laccases show their maximum activity at a temperature of $50.0^{\circ} \mathrm{C}$, while the free laccase shows the maximum activity at a temperature of $40.0^{\circ} \mathrm{C}$. So, the optimum temperatures were $50.0{ }^{\circ} \mathrm{C}$ and $40.0^{\circ} \mathrm{C}$ for immobilized and free laccase, respectively. $\mathrm{CuFe}_{2} \mathrm{O}_{4}$ nanoparticles and $\mathrm{Fe}_{3} \mathrm{O}_{4}$ nanoparticle-immobilized laccases retain $71.0 \%$ and $61.0 \%$ of their initial activity, respectively, at a temperature of $70.0{ }^{\circ} \mathrm{C}$, while the free enzyme retains only $23.0 \%$ of its activity at the same temperature. These results indicated the resistance of laccase on nanoparticles to conformational distortion, due to the cross-linking interaction between the nanoparticles and enzymes, which makes immobilized laccase resist the changes in environmental conditions, such as high temperatures. As expected, the $\mathrm{CuFe}_{2} \mathrm{O}_{4}$ nanoparticle-immobilized laccase showed higher resistance to temperature change than the $\mathrm{Fe}_{3} \mathrm{O}_{4}$ nanoparticleimmobilized laccase, due to the presence of copper ions, as discussed above.

\subsubsection{Kinetic Parameters}

By varying the substrate concentrations and measuring the initial reaction rates, according to the Lineweaver and Burk plots, we calculated the kinetic parameters (maximum velocity $\left(\mathrm{V}_{\max }\right)$ and Michaelis constant $\left(\mathrm{K}_{\mathrm{m}}\right)$ ) for free laccase, $\mathrm{Fe}_{3} \mathrm{O}_{4}$ immobilized laccase, and $\mathrm{CuFe}_{2} \mathrm{O}_{4}$ nanoparticle-immobilized laccase. The kinetic parameters for the free and immobilized laccases are presented in Table 1 . The affinity between the substrate and the enzyme is represented by the $\mathrm{K}_{\mathrm{m}}$ value. According to Table 1 , the $\mathrm{Fe}_{3} \mathrm{O}_{4}$ nanoparticleimmobilized laccase has the highest $\mathrm{K}_{\mathrm{m}}$ value, which is denoted by its requirement for a greater concentration of the substrate to reach the $V_{\max }$. The interaction between the enzymatic active sites and the substrate was hindered in the case of the immobilized enzymes, due to the steric hindrance that resulted from the nanoparticles laccase linkage and, subsequently, the $K_{m}$ values are higher for the immobilized laccase than the free one [37]. The irregular results of the $\mathrm{V}_{\max }$ and $\mathrm{K}_{\mathrm{m}}$ values in the case of the $\mathrm{CuFe}_{2} \mathrm{O}_{4}$ nanoparticleimmobilized laccase, when compared to the free laccase, resulted from the increased activity of laccase, due to the presence of copper ions. Also, the $\mathrm{Fe}_{3} \mathrm{O}_{4}$ nanoparticle-immobilized laccase showed the lowest value for $V_{\max }$, due to the reaction inhibition resulting from the accumulated product on the surfaces.

Table 1. Kinetic parameters for free laccase and nanoparticle-immobilized laccase.

\begin{tabular}{cccc}
\hline System & $\mathbf{V}_{\mathbf{m a x}}(\mathbf{U} / \mathbf{m L})$ & $\mathbf{K}_{\mathbf{m}}(\mathbf{m g} / \mathbf{m L})$ & $\mathbf{R}^{\mathbf{2}}$ \\
\hline Laccase@CuFe $\mathrm{O}_{4}$ & 34.80 & 3.64 & 0.95 \\
Laccase $@ \mathrm{Fe}_{3} \mathrm{O}_{4}$ & 30.93 & 3.76 & 0.97 \\
Free laccase & 33.60 & 3.65 & 0.96 \\
\hline
\end{tabular}

\subsection{Biodegradation of DR23 Dye}

\subsubsection{Effect of Dye Concentration}

The DR23 dye degradation using the $\mathrm{Fe}_{3} \mathrm{O}_{4}$ and $\mathrm{CuFe}_{2} \mathrm{O}_{4}$ nanoparticle-immobilized laccases was studied at different concentrations of the dye, ranging from $10.0 \mathrm{mg} / \mathrm{mL}$ to $50.0 \mathrm{mg} / \mathrm{mL}$, as shown in Figure 4a. The study of dye degradation at different concentrations of the dye was performed at optimum conditions, including a $\mathrm{pH}$ of 5.0 and a temperature of $50.0{ }^{\circ} \mathrm{C}$, using a nanobiocatalyst dosage of $300.0 \mathrm{mg} / \mathrm{mL}$. According to Figure $4 \mathrm{a}$, the increased dye concentration led to a decrease in the biodegradation of the dye in the case of both nanobiocatalysts. The high dye concentration may lead to 
failure to get the nanobiocatalyst/dye concentration to equilibrium state or, in some cases, the poisonousness of the nanobiocatalyst that causes decreased dye biodegradation with increased dye concentration [38]. Additionally, the low redox potential of the dye DR23 is responsible for the high affinity between the dye and both the nanobiocatalysts [39]. The $\mathrm{CuFe}_{2} \mathrm{O}_{4}$ nanoparticle-immobilized laccase showed a higher extent for DR23 degradation than the $\mathrm{Fe}_{3} \mathrm{O}_{4}$ nanoparticle-immobilized laccase, which could be attributed to the presence of copper ions. As discussed previously, the copper ions increase the catalytic properties of laccase, by binding to laccase through the copper-binding sites.

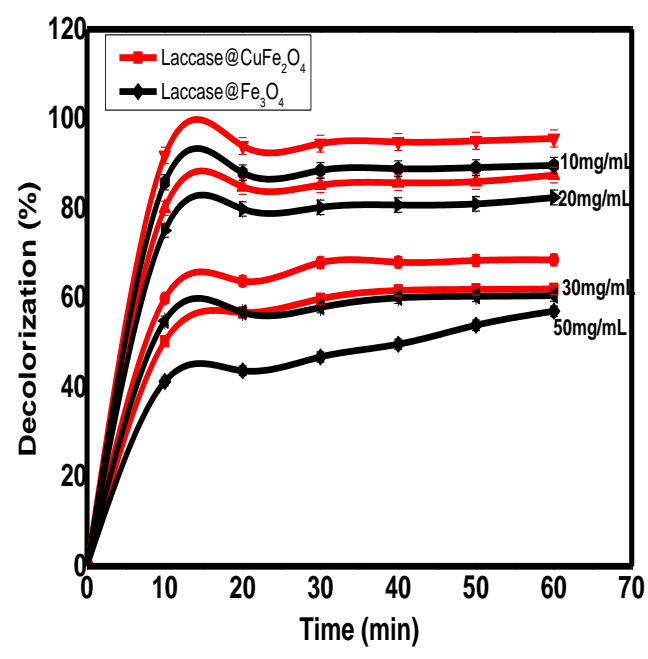

(a)

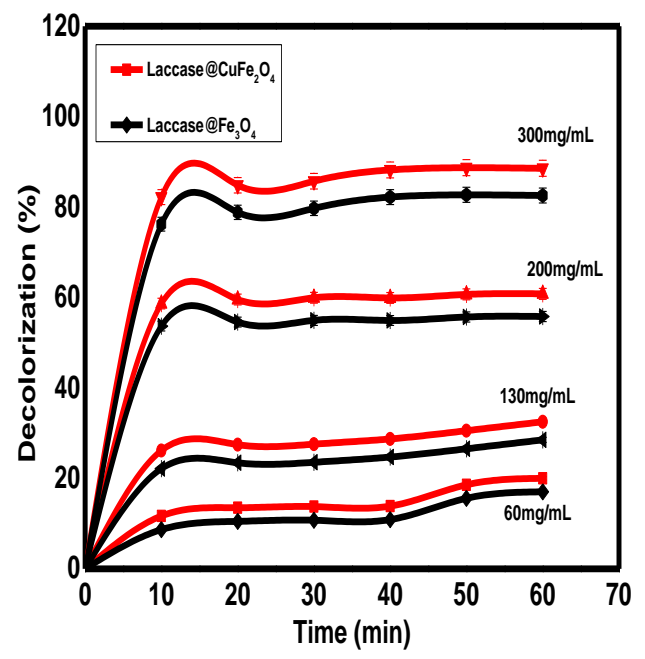

(b)

Figure 4. The effect of dye concentration (a) and the effect of nano-biosorbent dosage (b) for DR23 degradation using $\mathrm{Fe}_{3} \mathrm{O}_{4}$ and $\mathrm{CuFe}_{2} \mathrm{O}_{4}$ nanoparticle-immobilized laccase.

\subsubsection{Effect of Nanobiocatalyst Dosage}

DR23 dye degradation using the $\mathrm{Fe}_{3} \mathrm{O}_{4}$ and $\mathrm{CuFe}_{2} \mathrm{O}_{4}$ nanoparticle-immobilized laccases was studied at different nanobiocatalyst dosages, ranging from $60.0 \mathrm{mg} / \mathrm{mL}$ to $300.0 \mathrm{mg} / \mathrm{mL}$, as shown in Figure $4 \mathrm{~b}$. The study of dye degradation at different nanobiocatalyst dosages was performed at optimum conditions, including a $\mathrm{pH}$ of 5.0 and a temperature of $50.0^{\circ} \mathrm{C}$, using a dye concentration of $10.0 \mathrm{mg} / \mathrm{mL}$. According to Figure $4 \mathrm{~b}$, the increased dosage of the nanobiocatalyst caused an increase in the degradation of DR23, which could be attributed to the increased active sites of the enzymes with the added amount of the nanobiocatalyst [40]. DR23 dye showed a high affinity towards both the nanobiocatalysts. The results indicated that the most efficient dosage was $300.0 \mathrm{mg} / \mathrm{L}$ for $\mathrm{Fe}_{3} \mathrm{O}_{4}$ nanoparticles and $\mathrm{CuFe}_{2} \mathrm{O}_{4}$ nanoparticle-immobilized laccase, with the resultant dye degradation equal to $83.0 \%$ and $89.0 \%$, respectively. So, the expected results were obtained, in which the $\mathrm{CuFe}_{2} \mathrm{O}_{4}$ nanoparticles that were used as support for the laccase enzyme enhanced its catalytic activity for dye degradation, due to the presence of copper ions.

\subsubsection{The Mechanism of DR23 Biodegradation}

HPLC analysis was used to confirm the biodegradation of DR23 using $\mathrm{CuFe}_{2} \mathrm{O}_{4}$ nanoparticle-immobilized laccase, as shown in Figure 5. The HPLC analysis of the control solution containing DR23 dye showed the peak appearance at a retention time of $0.96 \mathrm{~min}$, as shown in Figure 5a. The HPLC analysis of DR23 dye using $\mathrm{CuFe}_{2} \mathrm{O}_{4}$ nanoparticleimmobilized laccase showed a reduction in the DR23 peak that appeared at the same retention time $(0.96 \mathrm{~min})$, with the appearance of an additional peak at a retention time of $1.73 \mathrm{~min}$, as shown in Figure $5 \mathrm{~b}$. The appearance of the new peak indicated the biodegradation of DR23 and the new peak was related to the degradation products. The other 
products of degradation may not appear in the HPLC analysis at the used wavelength [41]. The results indicated the successful biodegradation of DR23 dye using immobilized laccase on the surface of $\mathrm{CuFe}_{2} \mathrm{O}_{4}$ nanoparticles.

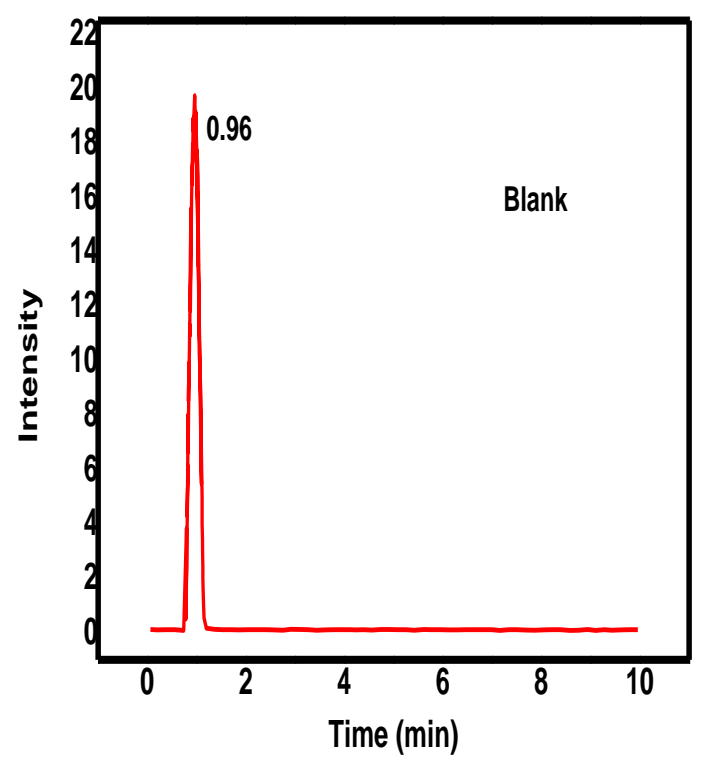

(a)

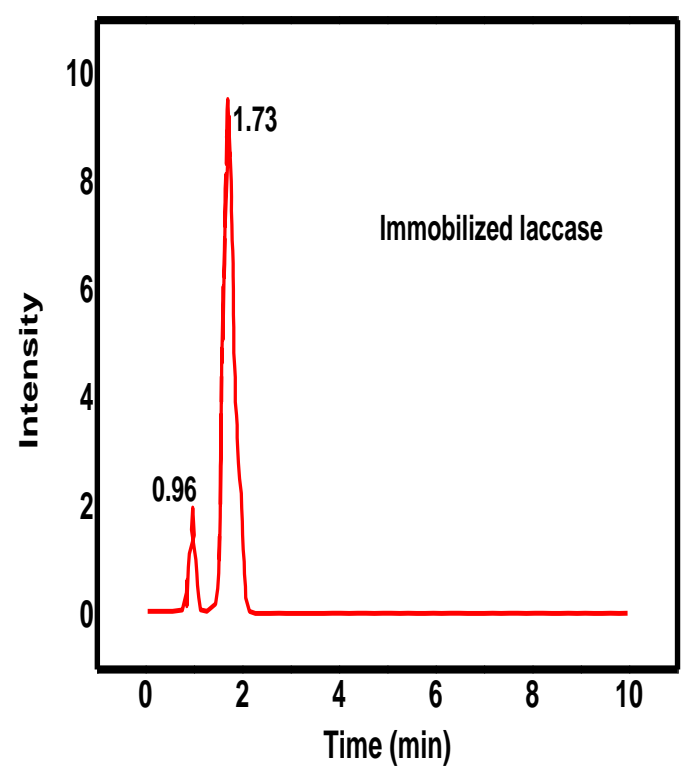

(b)

Figure 5. HPLC analysis of blank solution (a) and biodegraded DR23 dye solution using immobilized laccase (b).

The biodegradation of DR23 dye was reached through oxidation using the laccase to produce a phenolic ring that then oxidized to phenoxy radicals, and the radicals oxidized again to form carbonium ions. Then, unstable compounds were produced by the reaction of $\mathrm{H}_{2} \mathrm{O}$ with the phenolic carbon [41,42]. In the presence of oxygen, unstable compounds are removed. This biodegradation of DR23 was achieved due to the presence of copper sites in the laccase enzyme, which is responsible for the oxidation of the substrate and the reduction in oxygen to water by the type 1 site, and type 2 and 3, respectively. Hence, the presence of copper ions in the support enhanced the catalytic performance of the laccase enzyme. The biodegradation of DR23 produces four radicals from four substrate molecules and two $\mathrm{H}_{2} \mathrm{O}$ molecules from one oxygen molecule that represent the oxidation/reduction reaction [43]. The schematic representation of the azo dyes biodegradation mechanism using laccase enzyme is presented in the Supplementary Material (Scheme S1).

\subsubsection{Reusability}

Both nanoparticle-immobilized laccase $\left(\mathrm{Fe}_{3} \mathrm{O}_{4}\right.$ and $\left.\mathrm{CuFe}_{2} \mathrm{O}_{4}\right)$ were investigated for the degradation of DR23 dye several successive times, as shown in Figure 6. The reusability has great importance in minimizing the overall cost of treatment, minimizing the enzyme wastes, and increasing its industrial applicability [44-46]. According to Figure 6, there is higher relative reusability of both the nanobiocatalysts towards the degradation of DR23 dye, with a gradual decrease in the efficiency of decolorization from cycle 1 to cycle 5 . Cycle 1 showed the highest efficiency for both the nanobiocatalysts, while the last cycle showed the lowest efficiency.

This could attribute to the freshly used nanobiocatalyst in the first cycle. Reusing the nanobiocatalysts led to the protein leaching to the reaction medium, which caused the gradual decrease in the decolorization efficiency [47]. Also, the results indicated the higher reusability results for $\mathrm{CuFe}_{2} \mathrm{O}_{4}$ immobilized laccase than $\mathrm{Fe}_{3} \mathrm{O}_{4}$ immobilized laccase, indicating that $\mathrm{CuFe}_{2} \mathrm{O}_{4}$ nanoparticles are a better support for laccase than $\mathrm{Fe}_{3} \mathrm{O}_{4}$ nanoparticles. The decolorization efficiency of both the nanobiocatalysts was still over $70.0 \%$ after the 
sixth cycle, indicating the effective recovery and reusing of nanobiocatalysts. However, the $\mathrm{CuFe}_{2} \mathrm{O}_{4}$ nanoparticles as support caused enhanced catalytic activity for the laccase enzyme. Future studies must be focused on the determination of thermodynamic parameters [48-50] for enzyme immobilization, to get a full image about the nanobiocatalyst.

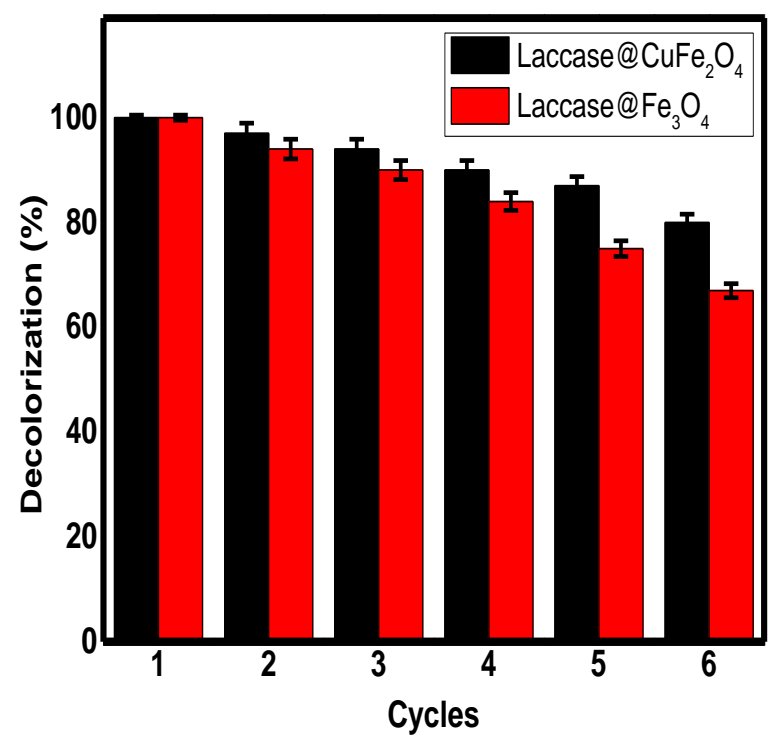

Figure 6. The reusability of $\mathrm{CuFe}_{2} \mathrm{O}_{4}$ nanoparticle-immobilized laccase for DR23 biodegradation up to six successive cycles in optimum conditions.

\section{Conclusions}

We can conclude that the use of nanoparticles for the immobilization of the laccase enzyme through amino functionalization enhanced its catalytic activity for the successful biodegradation of DR23 dye. The $\mathrm{CuFe}_{2} \mathrm{O}_{4}$ nanoparticle-immobilized laccase showed higher storage stability for 20 days at $4.0^{\circ} \mathrm{C}$ than the free laccase and $\mathrm{Fe}_{3} \mathrm{O}_{4}$ nanoparticleimmobilized laccase. Also, the $\mathrm{CuFe}_{2} \mathrm{O}_{4}$ nanoparticle-immobilized laccase showed higher activity in the $\mathrm{pH}$ range of 3.0 to 9.0 and temperature range of 30.0 to $70.0^{\circ} \mathrm{C}$. This higher laccase activity was attributed to the presence of copper ions that stimulated the laccase activity. Additionally, the $\mathrm{CuFe}_{2} \mathrm{O}_{4}$ nanoparticle-immobilized laccase showed higher biodegradation ability towards DR23 dye than the free laccase and $\mathrm{Fe}_{3} \mathrm{O}_{4}$ nanoparticleimmobilized laccase. The biodegradation of DR23 dye was confirmed by the HPLC results. Also, the immobilized laccase was investigated for the biodegradation of DR23 dye for up to six successive cycles, with good reusability results. Finally, the use of nanoparticles as support for the laccase enzyme can enhance their catalytic activity and enables their applicability in industrial applications.

Supplementary Materials: The following are available online at https:/ / www.mdpi.com/article/ 10.3390/app11178216/s1, Scheme S1: The mechanism of phenolic azo dye biodegradation using laccase enzyme.

Author Contributions: Conceptualization, F.B.R. and A.A.; methodology, N.S.A.; validation, F.B.R., F.M.A. and N.S.A.; formal analysis, K.M.K.; investigation, K.M.K.; resources, H.N.H.; data curation, H.N.H.; writing-original draft preparation, A.A.; writing—review and editing, N.S.A.; visualization, M.A.T.; supervision, M.A.T.; project administration, A.A.; funding acquisition, A.A. All authors have read and agreed to the published version of the manuscript.

Funding: This research was funded by Deanship of Scientific Research at King Khalid University. Also, this research was funded by the Deanship of Scientific Research at Princess Nourah bint Abdulrahman University through the Fast-track Research Funding Program.

Institutional Review Board Statement: Not applicable.

Informed Consent Statement: Not applicable. 


\section{Data Availability Statement: Not applicable.}

Acknowledgments: The authors extend their appreciation to the Deanship of Scientific Research at King Khalid University for funding this work through the research groups program under grant number RGP.1/111/42. Additionally, this research was funded by the Deanship of Scientific Research at Princess Nourah bint Abdulrahman University through the Fast-track Research Funding Program.

Conflicts of Interest: The authors declare no conflict of interest.

\section{References}

1. Kour, D.; Kaur, T.; Devi, R.; Yadav, A.; Singh, M.; Joshi, D.; Singh, J.; Suyal, D.C.; Kumar, A.; Rajput, V.D. Beneficial micro-biomes for bioremediation of diverse contaminated environments for environmental sustainability: Present status and future challenges. Environ. Sci. Pollut. Res. 2021, 28, 24917-24939. [CrossRef] [PubMed]

2. Overdahl, K.E.; Gooden, D.; Bobay, B.; Getzinger, G.J.; Stapleton, H.M.; Ferguson, P.L. Characterizing azobenzene disperse dyes in commercial mixtures and children's polyester clothing. Environ. Pollut. 2021, 287, 117299. [CrossRef] [PubMed]

3. Alderete, B.L.; da Silva, J.; Godoi, R.; da Silva, F.R.; Taffarel, S.R.; da Silva, L.P.; Garcia, A.L.H.; Júnior, H.M.; de Amorim, H.L.N.; Picada, J.N. Evaluation of toxicity and mutagenicity of a synthetic effluent containing azo dye after Advanced Oxidation Process treatment. Chemosphere 2021, 263, 128291. [CrossRef]

4. Rafiq, A.; Ikram, M.; Ali, S.; Niaz, F.; Khan, M.; Khan, Q.; Maqbool, M. Photocatalytic degradation of dyes using semiconductor photocatalysts to clean industrial water pollution. J. Ind. Eng. Chem. 2021, 97, 111-128. [CrossRef]

5. Kishor, R.; Purchase, D.; Saratale, G.D.; Ferreira, L.F.R.; Bilal, M.; Iqbal, H.M.; Bharagava, R.N. Environment friendly degradation and detoxification of Congo red dye and textile industry wastewater by a newly isolated Bacillus cohnni (RKS9). Environ. Technol. Innov. 2021, 22, 101425. [CrossRef]

6. Legerská, B.; Chmelová, D.; Ondrejovič, M. Decolourization and detoxification of monoazo dyes by laccase from the white-rot fungus Trametes versicolor. J. Biotechnol. 2018, 285, 84-90. [CrossRef] [PubMed]

7. Morsi, R.; Al-Maqdi, K.A.; Bilal, M.; Iqbal, H.; Khaleel, A.; Shah, I.; Ashraf, S.S. Immobilized Soybean Peroxidase Hybrid Bi-ocatalysts for Efficient Degradation of Various Emerging Pollutants. Biomolecules 2021, 11, 904. [CrossRef]

8. Aslam, S.; Asgher, M.; Khan, N.A.; Bilal, M. Immobilization of Pleurotus nebrodensis WC 850 laccase on glutaraldehyde cross-linked chitosan beads for enhanced biocatalytic degradation of textile dyes. J. Water Process. Eng. 2021, 40, 101971. [CrossRef]

9. Svetozarević, M.; Šekuljica, N.; Knežević-Jugović, Z.; Mijin, D. Agricultural waste as a source of peroxidase for wastewater treatment: Insight in kinetics and process parameters optimization for anthraquinone dye removal. Environ. Technol. Innov. 2021, 21, 101289. [CrossRef]

10. Zhang, K.; Yang, W.; Liu, Y.; Zhang, K.; Chen, Y.; Yin, X. Laccase immobilized on chitosan-coated Fe3O4 nanoparticles as reusable biocatalyst for degradation of chlorophenol. J. Mol. Struct. 2020, 1220, 128769. [CrossRef]

11. Tavares, A.P.; Silva, C.G.; Dražić, G.; Silva, A.; Loureiro, J.M.; Faria, J. Laccase immobilization over multi-walled carbon nanotubes: Kinetic, thermodynamic and stability studies. J. Colloid Interface Sci. 2015, 454, 52-60. [CrossRef]

12. Mehandia, S.; Sharma, S.; Arya, S.K. Immobilization of laccase on chitosan-clay composite beads to improve its catalytic efficiency to degrade industrial dyes. Mater. Today Commun. 2020, 25, 101513. [CrossRef]

13. Mohammadi, M.; As'Habi, M.A.; Salehi, P.; Yousefi, M.; Nazari, M.; Brask, J. Immobilization of laccase on epoxy-functionalized silica and its application in biodegradation of phenolic compounds. Int. J. Biol. Macromol. 2018, 109, 443-447. [CrossRef]

14. García-Morales, R.; Garcia, A.; Orona-Navar, C.; Osma, J.F.; Nigam, K.; Ornelas-Soto, N. Biotransformation of emerging pollutants in groundwater by laccase from P. sanguineus CS43 immobilized onto titania nanoparticles. J. Environ. Chem. Eng. 2018, 6, 710-717. [CrossRef]

15. Olshansky, Y.; Masaphy, S.; Root, R.A.; Rytwo, G. Immobilization of Rhus vernicifera laccase on sepiolite; effect of chitosan and copper modification on laccase adsorption and activity. Appl. Clay Sci. 2018, 152, 143-147. [CrossRef]

16. Bansal, M.; Kumar, D.; Chauhan, G.S.; Kaushik, A. Preparation, characterization and trifluralin degradation of lac-case-modified cellulose nanofibers. Mater. Sci. Energy Technol. 2018, 1, $29-37$.

17. Jiang, X.; Yu, Y.; Li, X.; Kong, X.Z. High yield preparation of uniform polyurea microspheres through precipitation polymeri-zation and their application as laccase immobilization support. Chem. Eng. J. 2017, 328, 1043-1050. [CrossRef]

18. Le, T.T.; Murugesan, K.; Lee, C.-S.; Vu, C.H.; Chang, Y.-S.; Jeon, J.-R. Degradation of synthetic pollutants in real wastewater using laccase encapsulated in core-shell magnetic copper alginate beads. Bioresour. Technol. 2016, 216, 203-210. [CrossRef] [PubMed]

19. Alsaiari, N.; Alzahrani, F.; Katubi, K.; Amari, A.; Rebah, F.; Tahoon, M. Polyethylenimine-Modified Magnetic Chitosan for the Uptake of Arsenic from Water. Appl. Sci. 2021, 11, 5630. [CrossRef]

20. Katubi, K.M.; Alzahrani, F.M.; Alsaiari, N.S.; Amari, A.; Rebah, F.B.; Tahoon, M.A. Partially Reduced Graphene Oxide Mod-ified with Polyacrylonitrile for the Removal of Sm3+ from Water. Processes 2021, 9, 818. [CrossRef]

21. Alzahrani, F.; Alsaiari, N.; Katubi, K.; Amari, A.; Ben Rebah, F.; Tahoon, M. Synthesis of Polymer-Based Magnetic Nanocomposite for Multi-Pollutants Removal from Water. Polymers 2021, 13, 1742. [CrossRef]

22. Amari, A.; Elboughdiri, N.; Ghernaout, D.; Lajimi, R.H.; Alshahrani, A.M.; Tahoon, M.A.; Rebah, F.B. Multifunctional cross-linked chitosan/nitrogen-doped graphene quantum dot for wastewater treatment. Ain Shams Eng. J. 2021, in press. [CrossRef] 
23. Alsaiari, N.S.; Katubi, K.M.M.; Alzahrani, F.M.; Siddeeg, S.M.; Tahoon, M.A. The application of nanomaterials for the electrochemical detection of antibiotics: A review. Micromachines 2021, 12, 308. [CrossRef]

24. Siddeeg, S.M.; Alsaiari, N.S.; Tahoon, M.A.; Rebah, F.B. The application of nanomaterials as electrode modifiers for the electrochemical detection of ascorbic acid. Int. J. Electrochem. Sci. 2020, 15, 3327-3346. [CrossRef]

25. Rani, M.; Shanker, U.; Chaurasia, A.K. Catalytic potential of laccase immobilized on transition metal oxides nanomaterials: Degradation of alizarin red S dye. J. Environ. Chem. Eng. 2017, 5, 2730-2739. [CrossRef]

26. Amari, A.; Alzahrani, F.M.; Alsaiari, N.S.; Katubi, K.M.; Rebah, F.B.; Tahoon, M.A. Magnetic metal organic framework immobilized laccase for wastewater decolorization. Processes 2021, 9, 774. [CrossRef]

27. Siddeeg, S.M.; Tahoon, M.A.; Mnif, W.; Ben Rebah, F. Iron Oxide/Chitosan Magnetic Nanocomposite Immobilized Manganese Peroxidase for Decolorization of Textile Wastewater. Processes 2019, 8, 5. [CrossRef]

28. Solé, M.; Müller, I.; Pecyna, M.J.; Fetzer, I.; Harms, H.; Schlosser, D. Differential Regulation by Organic Compounds and Heavy Metals of Multiple Laccase Genes in the Aquatic Hyphomycete Clavariopsis aquatica. Appl. Environ. Microbiol. 2012, 78, 4732-4739. [CrossRef] [PubMed]

29. Guo, L.-Q.; Lin, S.-X.; Zheng, X.-B.; Huang, Z.-R.; Lin, J.-F. Production, purification and characterization of a thermostable laccase from a tropical white-rot fungus. World J. Microbiol. Biotechnol. 2010, 27, 731-735. [CrossRef]

30. Maity, D.; Agrawal, D. Synthesis of iron oxide nanoparticles under oxidizing environment and their stabilization in aqueous and non-aqueous media. J. Magn. Magn. Mater. 2007, 308, 46-55. [CrossRef]

31. Gholinejad, M.; Karimi, B.; Mansouri, F. Synthesis and characterization of magnetic copper ferrite nanoparticles and their catalytic performance in one-pot odorless carbon-sulfur bond formation reactions. J. Mol. Catal. A Chem. 2014, 386, 20-27. [CrossRef]

32. Pavithradevi, S.; Suriyanarayanan, N.; Boobalan, T. Synthesis, structural, dielectric and magnetic properties of polyol assisted copper ferrite nano particles. J. Magn. Magn. Mater. 2017, 426, 137-143. [CrossRef]

33. Nadar, S.S.; Rathod, V.K. A co-immobilization of pectinase and cellulase onto magnetic nanoparticles for antioxidant extraction from waste fruit peels. Biocatal. Agric. Biotechnol. 2019, 17, 470-479. [CrossRef]

34. Kurian, J.; Mathew, M.J. Structural, optical and magnetic studies of $\mathrm{CuFe}_{2} \mathrm{O}_{4}, \mathrm{MgFe}_{2} \mathrm{O}_{4}$ and $\mathrm{ZnFe}_{2} \mathrm{O}_{4}$ nanoparticles prepared by hydrothermal/solvothermal method. J. Magn. Magn. Mater. 2018, 451, 121-130. [CrossRef]

35. Jamatia, R.; Gupta, A.; Pal, A.K. Superparamagnetic Copper Ferrite Nanoparticles Catalyzed One Step Regioselective Synthesis of Dibenzodiazepinones via Ligand and Base Free Ullmann Type Coupling Reaction. Chem. Sel. 2016, 1, 852-860. [CrossRef]

36. Muley, A.B.; Thorat, A.S.; Singhal, R.S.; Babu, K.H. A tri-enzyme co-immobilized magnetic complex: Process details, kinetics, thermodynamics and applications. Int. J. Biol. Macromol. 2018, 118, 1781-1795. [CrossRef]

37. Datta, R.S.; Gutteridge, A.; Swanton, C.; Maley, C.C.; Graham, T.A. Modelling the evolution of genetic instability during tumour progression. Evol. Appl. 2012, 6, 20-33. [CrossRef] [PubMed]

38. Mohajershojaei, K.; Khosravi, A.; Mahmoodi, N.M. Decolorization of dyes using laccase enzyme from single and binary sys-tems. Desalination Water Treat. 2014, 52, 1895-1902. [CrossRef]

39. Sayahi, E.; Ladhari, N.; Mechichi, T.; Sakli, F. Azo dyes decolourization by the laccase fromTrametes trogii. J. Text. Inst. 2015, 107, 1478-1482. [CrossRef]

40. Katuri, K.P.; Mohan, S.V.; Sridhar, S.; Pati, B.; Sarma, P. Laccase-membrane reactors for decolorization of an acid azo dye in aqueous phase: Process optimization. Water Res. 2009, 43, 3647-3658. [CrossRef]

41. Ramírez-Montoya, L.A.; Hernández-Montoya, V.; Montes-Morán, M.A.; Jáuregui-Rincón, J.; Cervantes, F.J. Decolorization of dyes with different molecular properties using free and immobilized laccases from Trametes versicolor. J. Mol. Liq. 2015, 212 , 30-37. [CrossRef]

42. Singh, R.L.; Singh, P.K.; Singh, R.P. Enzymatic decolorization and degradation of azo dyes-A review. Int. Biodeterior. Biodegrad. 2015, 104, 21-31. [CrossRef]

43. Guerrero, E.; Aburto, P.; Terrés, E.; Villegas, O.; González, E.; Zayas, T.; Hernández, F.; Torres, E. Improvement of catalytic efficiency of chloroperoxidase by its covalent immobilization on SBA-15 for azo dye oxidation. J. Porous Mater. 2012, 20, 387-396. [CrossRef]

44. Alsaiari, N.; Amari, A.; Katubi, K.; Alzahrani, F.; Rebah, F.; Tahoon, M. Innovative Magnetite Based Polymeric Nanocomposite for Simultaneous Removal of Methyl Orange and Hexavalent Chromium from Water. Processes 2021, 9, 576. [CrossRef]

45. Siddeeg, S.M.; Amari, A.; Tahoon, M.A.; Alsaiari, N.S.; Rebah, F.B. Removal of meloxicam, piroxicam and Cd ${ }^{+2}$ by $\mathrm{Fe}_{3} \mathrm{O}_{4} / \mathrm{SiO}_{2}$ /glycidyl methacrylate-S-SH nanocomposite loaded with laccase. Alex. Eng. J. 2020, 59, 905-914. [CrossRef]

46. Alzahrani, F.M.; Alsaiari, N.S.; Katubi, K.M.; Amari, A.; Elkhaleefa, A.M.; Rebah, F.B.; Tahoon, M.A. Magnetic Nitro-gen-Doped Porous Carbon Nanocomposite for Pb (II) Adsorption from Aqueous Solution. Molecules 2021, 26, 4809. [CrossRef] [PubMed]

47. Yang, D.; Wang, X.; Shi, J.; Wang, X.; Zhang, S.; Han, P.; Jiang, Z. In situ synthesized rGO-Fe $\mathrm{O}_{4}$ nanocomposites as enzyme immobilization support for achieving high activity recovery and easy recycling. Biochem. Eng. J. 2016, 105, 273-280. [CrossRef]

48. Gomaa, E.A.; Tahoon, M.A.; Negm, A. Aqueous micro-solvation of $\mathrm{Li}^{+}$ions: Thermodynamics and energetic studies of $\mathrm{Li}^{+}-\left(\mathrm{H}_{2} \mathrm{O}\right)_{\mathrm{n}}$ ( $\mathrm{n}=1-6)$ structures. J. Mol. Liq. 2017, 241, 595-602. [CrossRef]

49. Tahoon, M.; Gomaa, E.; Suleiman, M. Aqueous micro-hydration of $\mathrm{Na}^{+}\left(\mathrm{H}_{2} \mathrm{O}\right)_{\mathrm{n}}=1-7$ clusters: DFT study. Open Chem. 2019, 17, 260-269.

50. Gomaa, E.A.; Tahoon, M.A. Ion association and solvation behavior of copper sulfate in binary aqueous-methanol mixtures at different temperatures. J. Mol. Liq. 2016, 214, 19-23. [CrossRef] 